\title{
VANILLA YERSINIANA (ORCHIDACEAE), A NEW RECORD FOR PENINSULAR MALAYSIA
}

Received August 15, 2021; accepted October 07, 2021

MUHAMMAD IKHWANUDDIN MAT ESA

Department of Biology, Faculty of Science, Universiti Putra Malaysia, 43400 Serdang, Selangor, Malaysia.

E-mail:m.ikhwan_wan@yahoo.com

FARAH ALIA NORDIN

School of Biological Sciences, Universiti Sains Malaysia, 11800, Pulau Pinang, Malaysia.

E-mail: farahalianordin@usm.my

RUSEA GO

Department of Biology, Faculty of Science, Universiti Putra Malaysia, 43400 Serdang, Selangor, Malaysia.

E-mail: ruseago@upm.edu.my

AKMAL RAFFI

Faculty of Resource Science and Technology, Universiti Malaysia Sarawak, 94300, Kota Samarahan, Sarawak, Malaysia.E-mail: mrmakmal@unimas.my

\begin{abstract}
MAT ESA, M. I., NORDIN, F. A., GO, R. \& RAFFI, A. 2021. Vanilla yersiniana (Orchidaceae), a new record for Peninsular Malaysia. Reinwardtia 20(2): 51-55. — The genus Vanilla Plum. ex Mill. from Peninsular Malaysia is now enriched with the discovery of a newly recorded species, Vanilla yersiniana that made up its regional diversity to eight taxa. This species was documented from two adjacent secondary lowland forests in Perak; further south to the southern tail of Thailand. This paper describes the first record of $V$. yersiniana in Peninsular Malaysia with some highlights of its morphology and ecology. The data presented will add to the present state of knowledge on the species botanical profile.
\end{abstract}

Key words: Checklist, Malaysia, Orchidaceae, Vanilla.

\begin{abstract}
ABSTRAK
MAT ESA, M. I., NORDIN, F. A., GO, R. \& RAFFI, A. 2021. Vanilla yersiniana (Orchidaceae), rekaman baru dari Semenanjung Malaya. Reinwardtia 20(2): 51-55. - Marga Vanilla Plum. ex Mill. dari Semenanjung Malaya kini diperkaya dengan penemuan jenis baru yang tercatat, Vanilla yersiniana yang membentuk keragaman regionalnya menjadi delapan taksa. Jenis ini didokumentasikan di dua hutan dataran rendah sekunder yang berdekatan di Perak; lebih jauh ke selatan ke ekor selatan Thailand. Makalah ini menjelaskan catatan pertama $V$. yersiniana di Semenanjung Malaysia dengan beberapa sorotan morfologi dan ekologinya. Data yang disajikan akan menambah pengetahuan tentang profil botani terkini dari jenis ini.
\end{abstract}

Kata kunci: Daftar jenis, Malaysia, Orchidaceae, Vanilla.

\section{INTRODUCTION}

Orchidaceae is a fascinating plant family that allures researchers globally to study their systematics, ecophysiology and economical values. The current research trend on orchids in Malaysia focuses largely on the enumeration of the family composition. It is a never-ending task; with a relatively vast and unexplored forested land, Malaysian orchid's inventory is most likely far from being complete. To date, there are approximately 3000 orchid species recorded throughout Malaysia (Ong et al., 2017; Juiling et al., 2020;
Forest Department Sarawak, 2021). This figure is contributed by the series of novo discovery as well as the documentation of new regional record, which is also modelled by the local genus Vanilla - the subject matter of this paper. Generally, the genus Vanilla of Malaysia is represented by ten species of which seven of them can be found in Peninsular Malaysia (Ong, 2018; Raffi, 2019). However, the genus account in the peninsula is now enriched with the discovery of a species with distinct morphological characters from two adjacent localities in the state of Perak. Its initial population was spotted in January 2021 with indivi- 
duals bearing short sterile inflorescences (indicators of post-anthesis and unsuccessful fertilization) and the species identity was revealed two months later when three individuals were found flowering. This species was preliminary referred as $V$. albida Blume due to its high morphological resemblance but is later confirmed as $V$. yersiniana Guillaumin \& Sigaldi based on the taxonomic description and drawing by Averyanov (2011) as well as its matched distribution pattern that is centred in Indochina. In this paper, we present the new record of Vanilla species for Peninsular Malaysia, amended its morphological descriptions and provide important notes on the botanical profile. These data will add to the current knowledge on the genus from Malaysia, particularly from the peninsular region.

\section{MATERIALS AND METHODS}

In situ observations were conducted on the individuals of Vanilla from two localities in Lenggong, a valley located in the northern part of Perak, from January to July 2021. Flowering specimens were collected, dissected, preserved using the standard herbarium technique of Bridson and Foreman (1998) and deposited in the Herbarium of School of Biological Sciences, Universiti Sains Malaysia (USMP) (Thiers, 2021). Morphological characteristics of plants parts of the Vanilla were diagnosed and compared with the descriptions by Soto-Arenas \& Cribb (2010) and Averyanov (2011). The morphological characters of Vanilla yersiniana were described based on the Peninsular Malaysian specimen and its botanical drawing is provided.

\section{RESULTS AND DISCUSSION}

\section{TAXONOMIC TREATMENT}

VANILLA YERSINIANA Guillaumin \& Sigaldi, Bull. Mus. Nat. Hist. sér. 2, 36: 162. 1964. Figs. 1 \& 2. - Type: VIETNAM (Hon Ba), 26.03.1963, de Sigaldi 362, de Sigaldi 309 (Syntype P).

Hemiepiphytic, large creeping vine. Roots up to 4 $\mathrm{m}$ long. Stem to $10 \mathrm{~m}$ long or more; internodes 8.5 $-10 \mathrm{~cm}$ long, 8-9 $\mathrm{mm}$ in diam. Leaves $10-12 \times$
4-6 cm, narrowly ovate or broadly lanceolate, apex shortly acuminate, glossy green; petiole $c a$. $1.5 \mathrm{~cm}$ long. Inflorescence $2-5.5 \mathrm{~cm}$ long in total, bearing 4-10 flowers; peduncle $0.5-1.5 \mathrm{~cm}$ long; rachis 1-3 cm long; floral bract ca. $2 \mathrm{~mm}$ long, broadly triangular. Pedicel-with-ovary $2.8-3.2 \mathrm{~cm}$ long, terete, slightly curved, green. Flowers in succession, wide-opening, 6-8 cm across; sepals and petals white with greenish-yellow tint. Sepals broadly oblanceolate, ca. $5.5 \mathrm{~cm}$ long, $1.5 \mathrm{~cm}$ wide; petals a little smaller, $c a .5 \mathrm{~cm}$ long with adaxial keel along the median vein. Lip $c a .5 \mathrm{~cm}$ long, trumpet-shaped, forms a narrow tube at base, adnate to column margins for about $3 / 4$ of its length; base light yellow; apex white, rounded, 4 $\mathrm{cm}$ wide when spread out, margin slightly undulate to undulate; disc with an imbricate brush $c a .0 .7$ $\mathrm{cm}$ high by $0.5 \mathrm{~cm}$ wide, the apex with longitudinal rows of sparsely and shortly papillate hairs, 1$2.5 \mathrm{~mm}$ long, tinted red. Column ca. $4.5 \mathrm{~cm}$ long, slender, slightly curved, glabrous, whitish; lateral sides of clinandrium slightly undulate, reddish; rostellum $c a$. $0.5 \mathrm{~cm}$ long, rectangular; stigma 0.5 $\mathrm{cm}$ wide, transversely oblong to rectangular; apex irregularly incised with reddish margin, whitish yellow; anther-cap ca. $0.4 \mathrm{~cm}$ long, helmet-shaped, glabrous, greenish; pollinia granular. Fruit $12 \mathrm{~cm}$ long, cylindrical.

Distribution. Vietnam, Thailand and Peninsular Malaysia. In Peninsular Malaysia found in Perak.

Ecology. Climbing on trees, close to streams in secondary evergreen lowland forests.

Phenology. Flowering from March to May. Fruiting in March.

Notes. Vanilla yersiniana is a new record to Peninsular Malaysia. The lanceolate, long-acuminate leaves, whitish flowers and its scarcely developed papillae on lip apex distinguished this species from its closest ally, the $V$. albida. Tepals of $V$. albida are greener, and the lip is white with conspicuous trichomes at the apex of the lip (Cribb, 2014).

Specimen examined. Ikhwanuddin 11871 (USMP), Malaysia, Perak, Lenggong, $120 \mathrm{~m}$ elevation, 3 March 2021, flowering vine. 


\section{Key to Vanilla species from Peninsular Malaysia}

1a. Leaves reduced to small scales V. aphylla

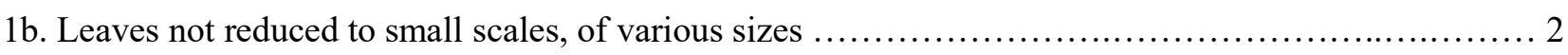

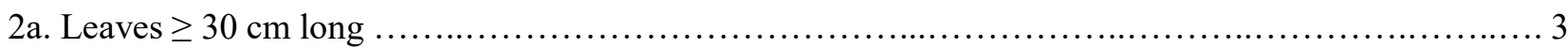

2b. Leaves $\leq 20 \mathrm{~cm}$ long 4

3a. Lip with veins blood-red forked or branched, midlobe with with tuft of hairs V. sumatrana

3b. Lip with purple-marked veins, midlobe with red-purple papillae at the apex V. kinabaluensis 4a. Lip apex deeply bilobed 5

4b. Lip apex entire 6

5a. Lip midlobe with dense horseshoe-shaped callus at the emarginated apex

V. griffithii

5b. Lip midlobe with single individual hairs arranged vertically towards the intersection of apical split ....... V. norashikiniana

6a. Lip with dense group of hairs at the apex V. pilifera

6b. Lip with sparsely arranged hairs at the apex 7

7a. Lip with single individual trichomes arranged in rows at the apex V. montana 7b. Lip with sparse short papillate hairs at the apex V. yersiniana
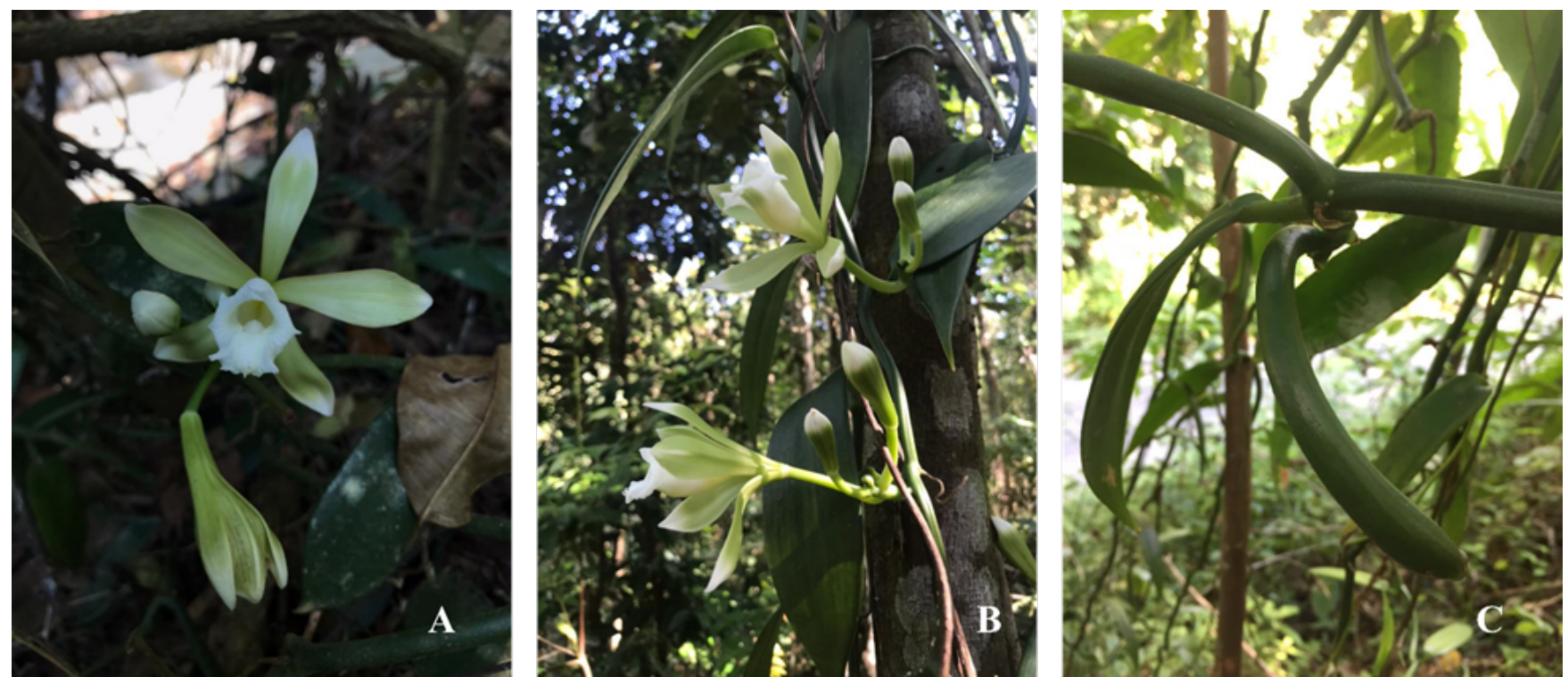

Fig. 1. Vanilla yersiniana in situ, Lenggong, Perak. A. Flower, front view. B. Vines with inflorescences at different flowering stages. C. Fruit. Photos by Ikhwanuddin. 


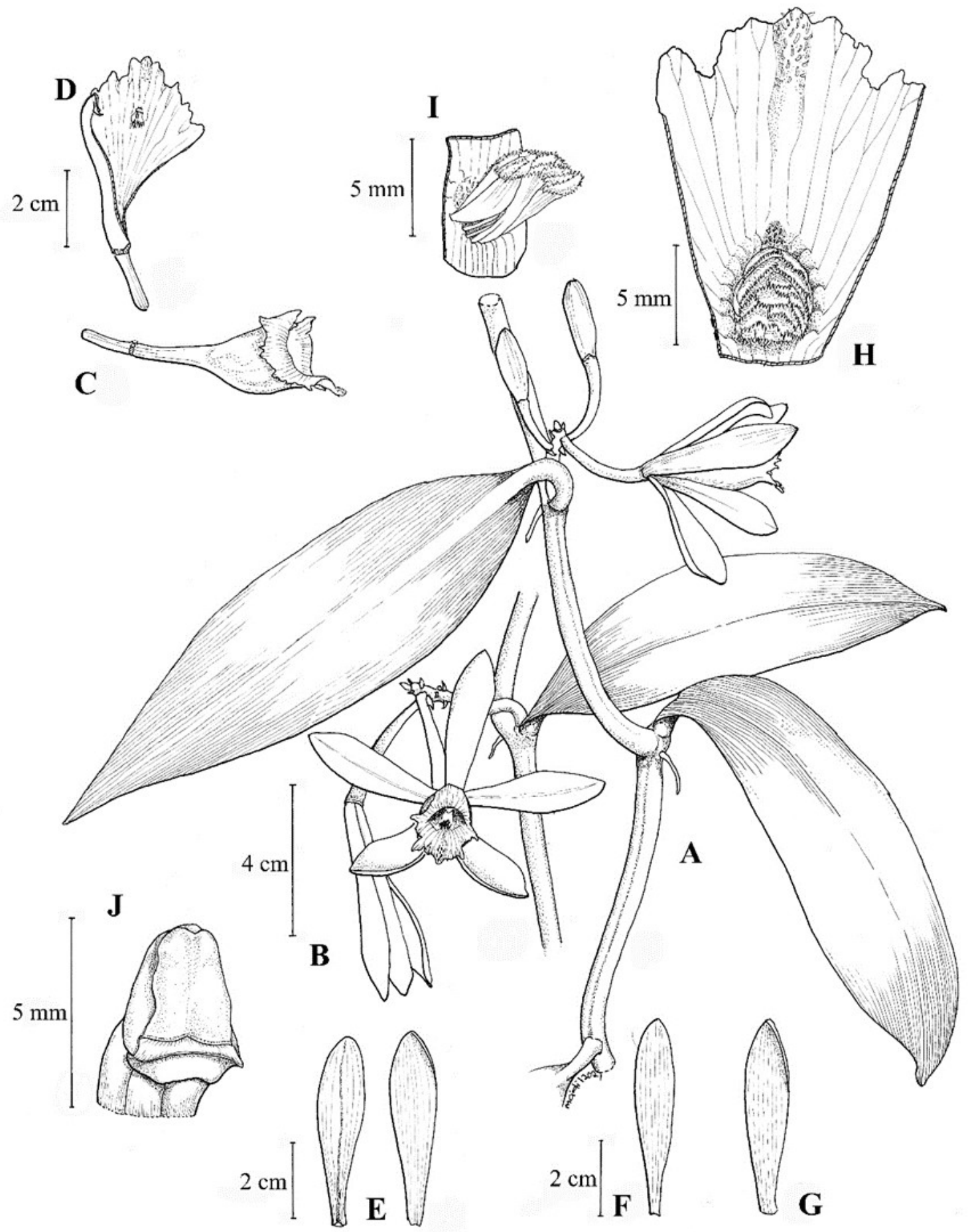

Fig. 2. Vanilla yersiniana. A. Part of flowering plant. B. Inflorescence with frontal view of flower. C. Lip, side view. D. Column with lip spread out. E. Petal, adaxial (left) \& abaxial (right). F. Dorsal sepal. G. Lateral sepal. H. Apical half of the lip disc showing the brush in the middle of the lip disc and hairs on apex. I. Imbricate brush on the lip disc. J. Column apex. From the herbarium specimen, Ikhwanuddin 11871 (USMP). Drawn by Mohamad Aidil Noordin. 


\section{ACKNOWLEDGEMENTS}

The authors would like to express our deepest gratitude to Department of Biology, Universiti Putra Malaysia, School of Biological Sciences, Universiti Sains Malaysia, and Faculty of Resource Science, Universiti Malaysia Sarawak for the facilities and assistance provided during the study conducted. Special thanks to Dato' Mohd Ridza Awang, Director General of Forestry Department of Peninsular Malaysia, Tuan Haji Roslan Rani, Director of Kedah State Forestry Department, and Dato' Mohamed Zin Yusop, Director of Perak State Forestry Department for granting access to the research locality with research permit number: KT7767-7775/2021. This project is funded by the American Orchid Society Grant (Grant No.: C-2020-17 and 304/PBIOLOGI/6501097/A151) awarded to the corresponding author, Farah Alia Nordin.

\section{REFERENCES}

AVERYANOV, L. V. 2011. The orchids of Vietnam illustrated survey. Part 3. Subfamily Epidendroideae (primitive tribes-Neottieae, Vanilleae, Gastrodieae, Nerviliea). Turczaninowia 14(2): 15-100.

CRIBB, P. 2014. A synopsis of Vanilla in Borneo. Malesian Orchid Journal 13: 101-112.

BRIDSON, D. \& FORMAN, L. 1998. The Herbarium Handbook. Kew Royal Botanic Gardens. United Kingdom.

FOREST DEPARTMENT SARAWAK. 2021. Facts and figures. https://forestry.sarawak.gov.my/page-0-4611170-FACTS-FIGURES.html. (Accessed 21 March 2021).

JUILING, S., LEON, S. K., JUMIAN, J., TSEN, S., LEE, Y. L., KHOO, E., SUGAU, J. B., NILUS, R., PEREIRA, J. T., DAMIT, A., TANGGARAJU, S., O'BYRNE, P., SUKAIBIN, S., MUJIH, H. \& MAYCOCK, C. R. 2020. Conservation assessment and spatial distribution of endemic orchids in Sabah, Borneo. Nature Conservation Research 5: 136144.

ONG, P. T., O'BYRNE, P., SAW, L. G. \& CHUNG, R. C. K. 2017. Checklist of Orchids of Peninsular Malaysia. Research Pamphlet No. 136. Forest Research Institute Malaysia. Kepong.

ONG, P. T. 2018. Flora of Peninsular MalaysiaVanilloideae. Malesian Orchid Journal 21: 69116.

RAFFI, A. 2019. 'Vanilla in Malaysia: Diversity and potential'. Presented at $13^{\text {th }}$ Asia Pacific Orchid Conference (APOC 13), Borneo Convention Centre Kuching, Sarawak, Malaysia. 25 July.

SOTO-ARENAS, M. A. \& CRIBB, P. 2010. A new infra-generic classification and synopsis of the Genus Vanilla Plum. ex Mill. (Orchidaceae: Vanillinae). Lankesteriana 9(3): 355-398.

THIERS, B. 2021. Index Herbariorum: a Global Directory of Public Herbaria and Associated Staff. New York Botanical Garden's Virtual Herbarium (Continuously updated). https:// sweetgumnybg.org/science/ih. (Accessed 27 August 2021). 
